\title{
GEOCHEMICAL AND MINERALOGICAL STUDIES OF CRYSTALLINE LIMESTONE OCCURRED NEAR PODUPATTI VILLAGE OF ETTAYAPURAM TALUK, TAMIL NADU
}

Jayant Kumar Padhi ${ }^{1}$, Amar Kumar Mishra ${ }^{2}$, Sadasiba Jena ${ }^{3}$ and Dr. G.R. Senthil Kumar ${ }^{4}$

\begin{abstract}
The present study deals with the chemical and mineralogical measurements of the crystalline limestone and its country rocks occurred in the study area. The limestone band consists pink and greyish-white limestones and the country rocks calc-gneiss and charnockite. The geochemical and the mineralogical studies were conducted in the limestone and the country rocks with the help of XRF and XRD instruments. The oxide and element concentrations were assessed with the help of XRF and the minerals were studied with XRD. The XRF result demonstrates that the pink limestone consists $\mathrm{CaO}$ of $51.15 \%$ and the greyish-white consist $52.00 \%$. The $\mathrm{SiO}_{2}$ is 10.19 and $9.69 \%$ in pink and greyish-white limestone respectively. Apart from them, four major oxides were reported, which are $\mathrm{Fe}_{2} \mathrm{O}_{3}, \mathrm{Na}_{2} \mathrm{O}, \mathrm{Al}_{2} \mathrm{O}_{3}$ and $\mathrm{MgO}$. All together they account for $5.21 \%$ in pink limestone and $3.98 \%$ in greyish-white limestone. The elemental concentration reveals that $\mathrm{Ca}$ in higher level and followed by Si. In the country rocks, Si Wt\% is high and followed by $\mathrm{Ca}$ and $\mathrm{Fe}$. According to XRD result, the pink limestone contains about $80.3 \%$ of calcite and $19.7 \%$ of quartz minerals, whereas in greyish-white limestone about $68.4 \%$ of calcite, $21.2 \%$ of diopside and $10.4 \%$ of quartz minerals. The country rock calc-gneiss loaded with silica (50.85\%), $\mathrm{Al} 2 \mathrm{O} 3(18.15 \%)$ and $\mathrm{CaO}$ (16.25\%). In charnockite, the major oxides are $\mathrm{SiO}_{2}(45.60 \%), \mathrm{Fe}_{2} \mathrm{O}_{3}(15.12 \%), \mathrm{Al}_{2} \mathrm{O}_{3}(10.84 \%)$, $\mathrm{Na}_{2} \mathrm{O}(10.12 \%)$ and $(9.14 \%)$. The study area limestone is dominated by calcite mineral, along with quartz and diopside.
\end{abstract}

Keywords - Crystalline limestone, Calc-gneiss, Charnockite, Geochemistry, XRF and XRD.

\section{INTRODUCTION}

Geochemical analysis is the analysis performed on a substance to know its chemical composition, concentration of the composition as well as various chemical properties to diagnose the substance. Through chemical analysis, content of some element or group of elements is measured. Geological investigation of mineral resources is extremely dependent upon the chemical analyses of the mineral. The geochemical study being naturally occurring material which may include rock, soil, gossan, glacial debris, vegetation, stream sediment, ocean floor sediments or water etc [1]. Limestone is one of the important industrial rocks that are presently gaining dominance in the manufacturing sector of the Indian economy

\footnotetext{
${ }^{1}$ Department of Earth Sciences, Annamalai University, Tamil Nadu - 608002.

${ }^{2}$ Department of Earth Sciences, Annamalai University, Tamil Nadu - 608002.

${ }^{3}$ Department of Earth Sciences, Annamalai University, Tamil Nadu - 608002.

${ }^{4}$ Associate Professor, Department of Earth Sciences, Annamalai University, Tamil Nadu- 608002.
} 
[2]. Limestone is the major raw material required for the evergrowing cement industry [4]. India is the second largest producer of cement in the world, and such a large scale production has put a stress on the cement grade limestone reserves. This compels the exploration work to go beyond the sedimentary limestone to the meta-sedimentary formations. The oldest limestone seen in India occurs along with the other meta-sedimentary magmatic formations as part of the Archean basement [4]. Complex with tiny periods the increased temperature and pressure altered the original textural, mineralogical and structural characteristics of the calcareous sediments to coarse grained crystalline limestone with other metamorphic mineral assemblages [4]. The aim of this study is to understand the geochemical constituents of crystalline limestone and its host rocks occurred in the study area.

\section{STUDY AREA}

The chosen study area falls in the Survey of India toposheet number 58G/16 on a scale of 1:50,000. The latitudes are $9^{\circ} 1^{\prime} 59^{\prime \prime} \mathrm{N}$ and $9^{\circ} 2^{\prime} 12^{\prime \prime} \mathrm{N}$ and the longitudes are $77^{\circ} 58^{\prime} 51^{\prime \prime} \mathrm{E}$ to $77^{\circ} 58^{\prime} 54^{\prime \prime} \mathrm{E}$. The study area, Podupatti is located in the Ettayapuram Taluk of Thoothukudi District, Tamil Nadu, and is located at a distance of $19 \mathrm{~km}$ from the Ettayapuram Town. The district headquarters, Thoothukudi Town lays in the south-east of the study area at a distance of about $45 \mathrm{~km}$. The study area is located at a distance of $24 \mathrm{~km}$ from Kovilpatti town and about $4.5 \mathrm{~km}$ from Pasuvanthanai. The Podupatti village is located towards the north of the study area with a distance of about $1 \mathrm{~km}$.

The study area receives very less rainfall throughout the year. The major monsoon season is from October to December $[5,6]$. The topsoil of the locality includes black soil, which indicates its low fertility Thus, thorny bushes, as well as, dry crop cultivation are observed in the locality. The area lies at a distance of $25 \mathrm{~km}$ from the coastline. The average elevation of the area is about $60 \mathrm{~m}$ above mean sea level (MSL). It is a plain terrain shown by the absence of any high relief features. The location map of the study area is shown in Figure 1.

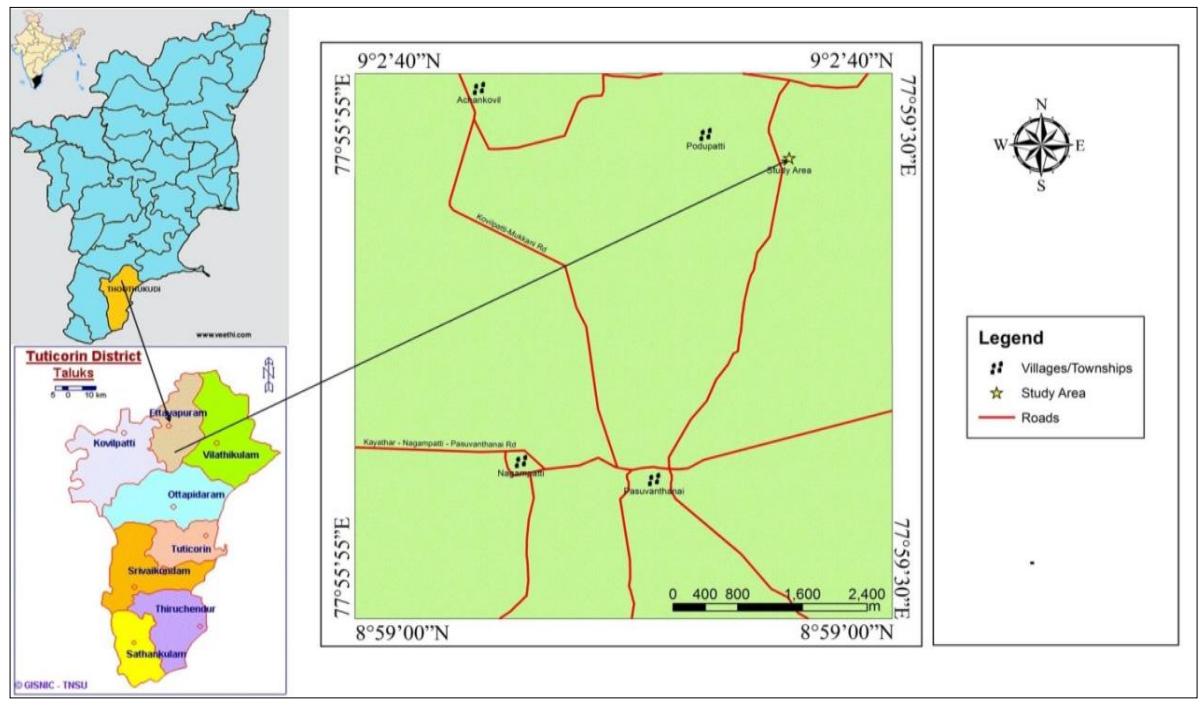

Figure 1: Location map of the study area

\section{GEOLOGY}

Signs of high-end metamorphism indicated that the study area belongs to Archean period. The limestone in the area occurred as a linear band. Crystalline limestone being very plastic material under metamorphic conditions develops thickening and thinning characteristics. Due to plastic deformation, tectonic inclusions are often incorporated by the limestone, which floats within the limestone as large 
scale impurities [4]. Owing to metamorphism and deformation, some folded structures are appearing in the limestone band. The band is often intercalated with gneissic materials. Patches of charnockites are also encountered in the study area. The limestone exhibits pink and greyish-white colour, the pink limestone is more common than the greyish-white. The general impurities are quartz, diopside and apatite. The limestone band consists of a large quantity of ferromagnesian minerals, which occurs sporadically throughout the band. Quartzite intrusions are often in the band. Quartzites are the oldest of the rock types followed by limestone and other rocks. The saccharoidal forms of free quartz are commonly associated with the limestone. The limestone band is relatively narrow and has less width in the top and bottom portions; however, the centre of the band is found to be exaggerated wide. The length of the limestone band is about $320 \mathrm{~m}$ with an average width of around $36 \mathrm{~m}$. The maximum width at the centre is about $54 \mathrm{~m}$. Due to intense metamorphism and folding the width developed at the centre. The general strike of the limestone band is N-S direction with dips of $50^{\circ}$ towards east. The Geological map of the study area is shown in Figure 2.

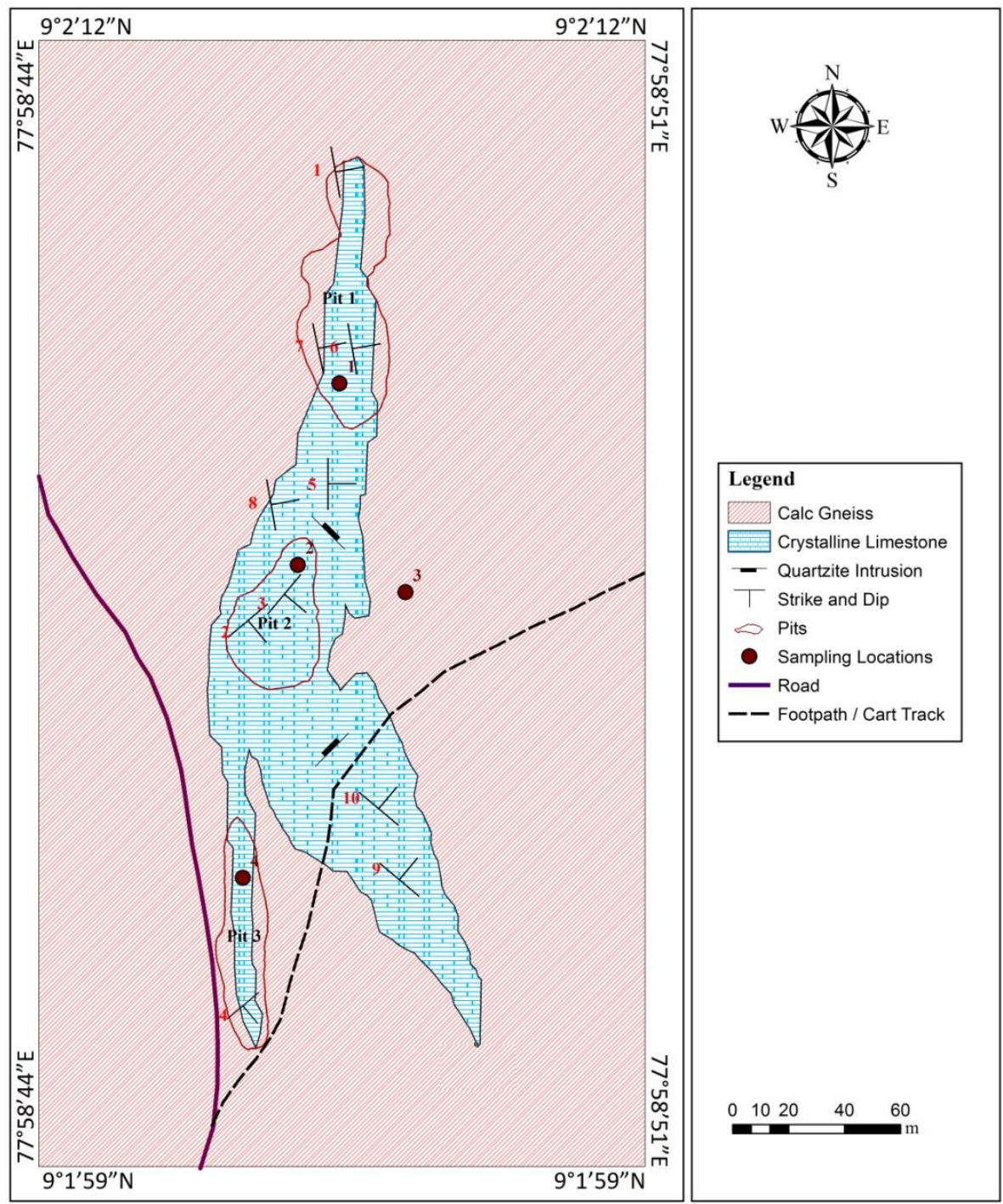

Figure 2: Geological map and sampling locations are shown 


\section{METHODOLOGY}

\section{A. Sample collection-}

Representative samples were collected from the limestone and country rocks. As a total, four samples were collected from the study area. Two samples from the limestones which include the pink and greyishwhite. The sample locations are Loc. 1 (PLST) and Loc. 2 (WLST) and the remaining from the country rocks, including calc- gneiss Loc.3 (CGR) and charnockite Loc.4 (CHR). The sampling locations are shown in Figure 2.

\section{B. Sample preparation-}

The collected samples were crushed and powdered using iron and agate mortar. The samples were powdered to a suitable size for the geochemical analysis. The powdered samples were labelled separately for XRF and XRD analysis.

\section{Analytical methods-}

The geochemical measurements of the samples collected from the study area were done by XRF and XRD analytical methods. XRF is widely used among researchers for geochemical analyses [7-9]. The XRF analysis was performed at CECRI, Karaikudi. The detected XRF instrument is Horiba XGT microXRF analyser (Model: XGT 2700 X-ray analytical microscope). HORIBA's XGT systems provide energy dispersive X-ray fluorescence (EDXRF) analysis. High intensity X-ray beams with diameters ranging from $3 \mathrm{~mm}$ down to a unique $10 \mu \mathrm{m}$ are used in the system to obtain full qualitative and quantitative elemental analysis. The system uses a Rh-target X-ray tube with tube voltage $50 \mathrm{kV}$ and current $1 \mathrm{~mA}$. The fluorescent X-ray beams are detected by a silicon based SDD detector. The specifications of the instrument are given in Table 1.

Table -1 Specifications of the Horiba XGT-2700 micro XRF analyser

X-ray source

Fluorescent X-ray detector

Transmitted X-ray detector

$\mathrm{X}$-ray guide tube

Detectable elements

Samples

CCD camera

Signal processing
Rh target / Tube voltage 50kV / Tube current $1 \mathrm{~mA}$

Eltier cooled Silicon Drift Detector (SDD)

Nai(Tl) scintillator

Mono capillary $10 \mu \mathrm{m} / 100 \mu \mathrm{m}$ with no filter

Sodium to Uranium (Atomic numbers 11 to 92)

Metal plates, powders and coatings

Magnification 30 and 100 approx.

Digital pulse processor

XRD is popular among scientists for mineral identification [4, 10, and 11]. The X-ray diffractometer used for the analysis of the samples is a product of PANalytical Company distributed by Spectris 
Technologies Pvt. Ltd., (Model: PANalytical X'Pert ${ }^{3}$ Powder model). The specifications of the X'Pert ${ }^{3}$ Powder model is given in Table 2.

Table -2 System Specifications of PANalytical X'Pert ${ }^{3}$ Powder model

X-ray source

Generator: $3 \mathrm{~kW}$ generator supporting all current and future X-ray Tubes

Standard sealed X-ray tube : $\mathrm{Cu}$, Co radiation

Direct optical encoding positioning system (DOPS) for lifetime goniometer accuracy

Detector Curvature radius : 240mm

Maximum usable range (depending on accessories) $40^{\circ}<2 \theta<220^{\circ}$

$\begin{array}{ll}\begin{array}{l}\text { Goniometric } \\ \text { table }\end{array} & \text { Vertical goniometer (theta-theta) } \\ & \text { Fixed, with or without sample rotation }\end{array}$

Sample holders

$\begin{array}{ll}\text { Dimensions } & 1972(\mathrm{~h}) \times 1370(\mathrm{w}) \times 1131(\mathrm{~d}) \mathrm{mm} \\ \text { Weight } & 1100 \mathrm{~kg} \\ \text { Computer } & \text { Windows } \bigodot 8 \text { OS } \\ \text { Software } & \text { Match 3- For Search and matching of minerals as per their peaks } \\ \text { Database used } & \text { COD- Crystallographic Open Database }\end{array}$

\section{RESULTS AND DISCUSSION}

A. Major oxides-

Through XRF analysis, oxide concentrations were measured in the rock samples collected from the study area. The result indicates that the study area crystalline limestone Loss on Ignition (LOI) is $33.40 \%$ for pink limestone and $34.29 \%$ for greyish-white limestone. The major oxides reported are, $\mathrm{CaO}, \mathrm{SiO}_{2}, \mathrm{Fe}_{2} \mathrm{O}_{3}$, $\mathrm{Na}_{2} \mathrm{O}, \mathrm{Al}_{2} \mathrm{O}_{3}$ and $\mathrm{MgO}$. The limestones are mainly rich in calcium content which is $51.15 \%$ in pink

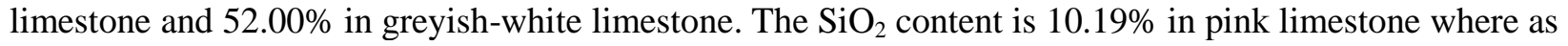
in greyish white limestone it is $9.69 \%$. The $\mathrm{Fe}_{2} \mathrm{O}_{3}$ content of the limestones is $1.69 \%$ in greyish-white limestone and $1.03 \%$ in pink limestone. The $\mathrm{MgO}$ in pink limestone is more than that of the greyish-white limestone which is $2.17 \%$ in the former and $1.97 \%$ in the latter. The $\mathrm{Al}_{2} \mathrm{O}_{3}$ of pink and white limestone are $1.37 \%$ and $0.59 \%$ respectively. Both the limestone has less than $1 \% \mathrm{Na}_{2} \mathrm{O}$ content. Pink limestone has $0.18 \%$ whereas greyish-white limestone has $0.19 \%$ of $\mathrm{Na}_{2} \mathrm{O}$. The LOI of country rocks is $2.45 \%$ and $1.12 \%$ in calc-gneiss and charnockite respectively. The calc-gneiss, is rich in silica content, which has $50.85 \%$ and is followed by calcium oxide $(16.25 \%)$. The $\mathrm{CaO}$ content of the charnockite is $9.14 \%$. The 
charnockite is rich in silica and ferro-magnesian content which is displayed by a dominating $45.60 \%$ of silica and followed by $15.12 \%$ of iron oxide and $8.05 \%$ of magnesium oxide respectively. Among the samples, charnockite has more magnesia content (8.05\%) than the others; the calc-gneiss has $2.50 \%$. The country rocks have higher alumina content than the limestones. The alumina in calc-gneiss and charnockite is $18.15 \%$ and $10.84 \%$ respectively. The country rocks have sodium contents of $9.12 \%$ and $10.12 \%$ in calc-gneiss and charnockite respectively. The oxide composition of the samples are shown in Table 3.

Table- 3 Oxide composition (\%) in the representative samples collected from the study area

$\begin{array}{llllll} & \text { Sample } & \text { PLST } & \text { WLST } & \text { CGR } & \text { CHR } \\ \begin{array}{l}\text { SI } \\ \text { No. }\end{array} & \text { Rocks } & \text { Pink limestone } & \begin{array}{l}\text { Greyish-white } \\ \text { limestone }\end{array} & \text { Calc-gneiss } & \text { Charnockite } \\ \mathbf{1} & \mathbf{C a O} & 51.15 & 52.00 & 16.25 & 9.14 \\ \mathbf{2} & \mathbf{S i O}_{2} & 10.19 & 9.69 & 50.85 & 45.60 \\ \mathbf{3} & \mathbf{F e}_{2} \mathbf{O}_{3} & 1.69 & 1.03 & 0.66 & 15.12 \\ \mathbf{4} & \mathbf{N a}_{2} \mathbf{O} & 0.18 & 0.19 & 9.12 & 10.12 \\ \mathbf{5} & \mathbf{A l}_{\mathbf{2}} \mathbf{O}_{3} & 1.37 & 0.59 & 18.15 & 10.84 \\ \mathbf{6} & \mathbf{M g O} & 1.97 & 2.17 & 2.50 & 8.05 \\ \mathbf{7} & \mathbf{L O I} & 33.40 & 34.29 & 2.45 & 1.12\end{array}$

B. Major elements-

The XRF findings revealed that, six major elements reported in varying $\mathrm{Wt} \%$. The reported elements are shown in Table 4. Among the elements, $\mathrm{Ca}$ account for highest $\mathrm{Wt} \%$ in the limestone, the weight percentages are 36.56 and $37.16 \mathrm{Wt} \%$ of pink and greyish-white limestone samples correspondingly. The $\mathrm{Si}$ content in the pink limestone, is 4.76 and in the greyish-white limestone is $4.52 \mathrm{Wt} \%$. The $\mathrm{Fe}$ and $\mathrm{Mg}$ $\mathrm{Wt} \%$ in the pink limestone is 1.18 and 1.20. In greyish-white limestone, the Fe and $\mathrm{Mg}$ are 0.72 and $1.31 \mathrm{Wt} \%$. The pink and greyish-white limestone has aluminum of 0.72 and $0.31 \mathrm{Wt} \%$. The sodium content of pink and greyish-white limestone is $0.13 \%$ and $0.14 \%$ respectively. The $\mathrm{Ca}$ in calc-gneiss is 11.615 and in charnockite, it is $6.53 \mathrm{Wt} \%$. The silica in the calc-gneiss and charnockite are 23.76 and $21.31 \mathrm{Wt} \%$ respectively. The charnockite is, however, rich in iron and magnesium content. The charnockite has iron and magnesium of $10.57 \%$ and $4.85 \%$, respectively, however the calc-gneiss has the iron $(04 \mathrm{Wt} \%)$ and magnesium $(1.50 \mathrm{Wt} \%)$. The sodium content of calc-gneiss and charnockite are $6.76 \%$ and $7.50 \%$ respectively. The aluminum $\mathrm{Wt} \%$ in calc-gneiss is $9.6 \mathrm{Wt} \%$ and in charnockite it is $5.73 \mathrm{Wt} \%$. The Table 4 shows the major elemental composition in the samples collected in the area. 
Table 4: Elements composition (\%) of representative samples collected from the study area

\begin{tabular}{|c|c|c|c|c|c|}
\hline & Sample & PLST & WLST & CGR & CHR \\
\hline No. & Rocks & Pink limestone & $\begin{array}{l}\text { Greyish-white } \\
\text { limestone }\end{array}$ & Calc-gneiss & Charnockite \\
\hline 1 & $\mathbf{C a}$ & 36.56 & 37.16 & 11.61 & 6.53 \\
\hline 2 & $\mathbf{S i}$ & 4.76 & 4.52 & 23.76 & 21.31 \\
\hline 3 & $\mathbf{F e}$ & 1.18 & 0.72 & 0.46 & 10.57 \\
\hline 4 & $\mathrm{Na}$ & 0.13 & 0.14 & 6.76 & 7.50 \\
\hline 5 & Al & 0.72 & 0.31 & 9.60 & 5.73 \\
\hline 6 & Mg & 1.20 & 1.31 & 1.50 & 4.85 \\
\hline
\end{tabular}

C. Mineralogy -

The X-ray diffraction method is an easy and accurate method for identification of mineral phases present in the samples [10]. The mineral formation in the limestone and country rocks was identified with the help of Match 3 software which uses Crystallographic Open Database (COD) as the reference database. The COD collects all known 'small molecule / small to medium sized unit cell' crystal structures and makes them available freely on the internet [12]. The XRD results shows that the calcite is the most dominating mineral in both greyish-white and pink limestones followed by quartz. The greyishwhite limestone contains the minerals of calcite $(68.4 \%)$, diopside $(21.2 \%)$ and quartz $(10.4 \%)$ as coesite as shown by X-ray pattern graphics. The pink limestone contains the minerals calcite $(80.3 \%)$ and quartz $(19.7 \%)$ as low quartz as counted by the several XRD peaks. The calc-gneiss rock possess the minerals such as calcite $(34.1 \%)$, scapolite $(28.2 \%)$, quartz (17.7\%), enstatite $(12.4 \%)$, diopside $(4.4 \%)$ and augite (3.3\%). The granulitic rock consists of minerals such as orthoclase, bytownite, anorthite, hornblende, diopside, apatite, quartz and dolomite. The rock consists of $25 \%$ of orthoclase, $23.2 \%$ of bytownite, $18 \%$ of anorthite, $14 \%$ of hornblende, $8,1 \%$ of diopside, $4.7 \%$ quartz and $1.9 \%$ of dolomite as per the XRD peak calculation. The apatite occurs as a greenish cover over the rock. The XRD patterns of the samples are shown in Figure 3, 4, 5 and 6 respectively. 
Geochemical And Mineralogical Studies Of Crystalline Limestone Occurred Near Podupatti Village Of Ettayapuram Taluk, Tamil Nadu

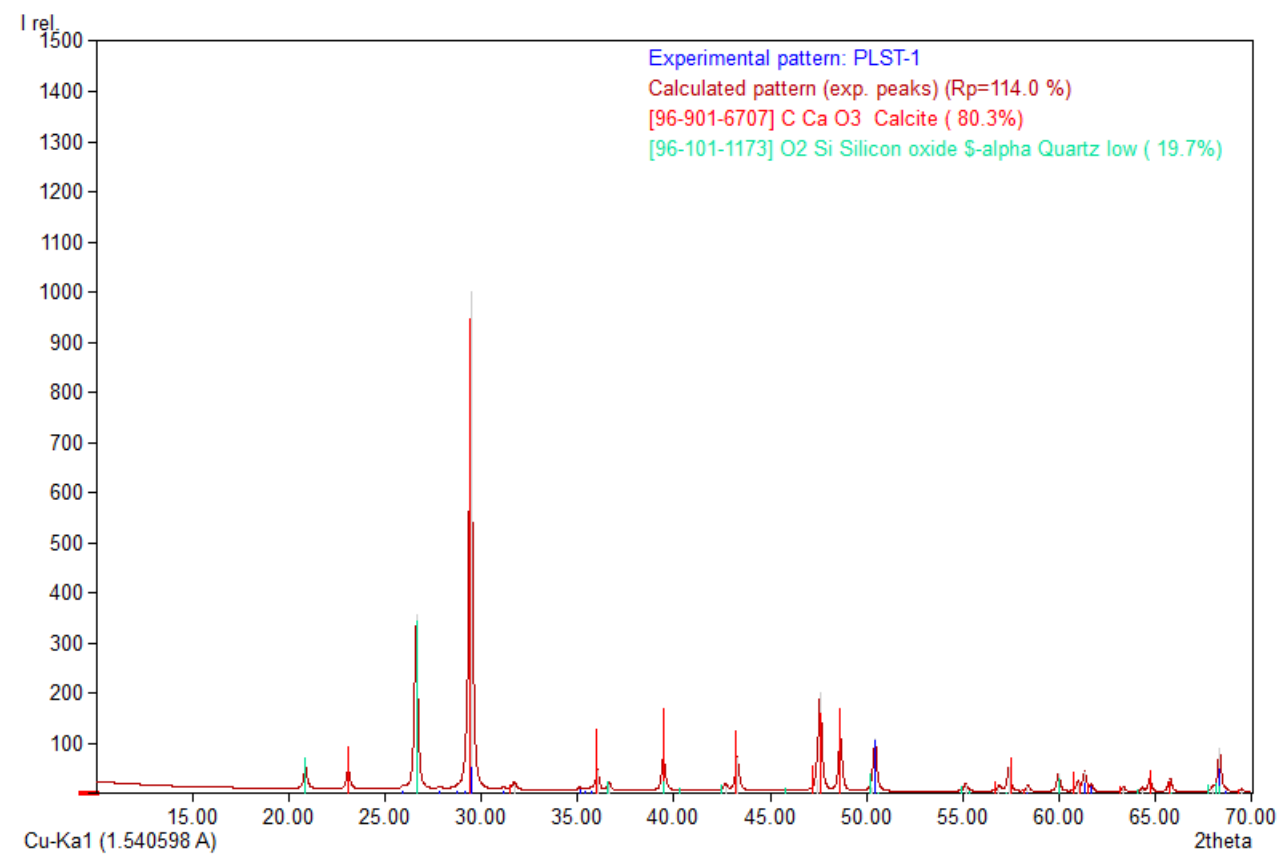

Figure 3: XRD pattern of pink limestone

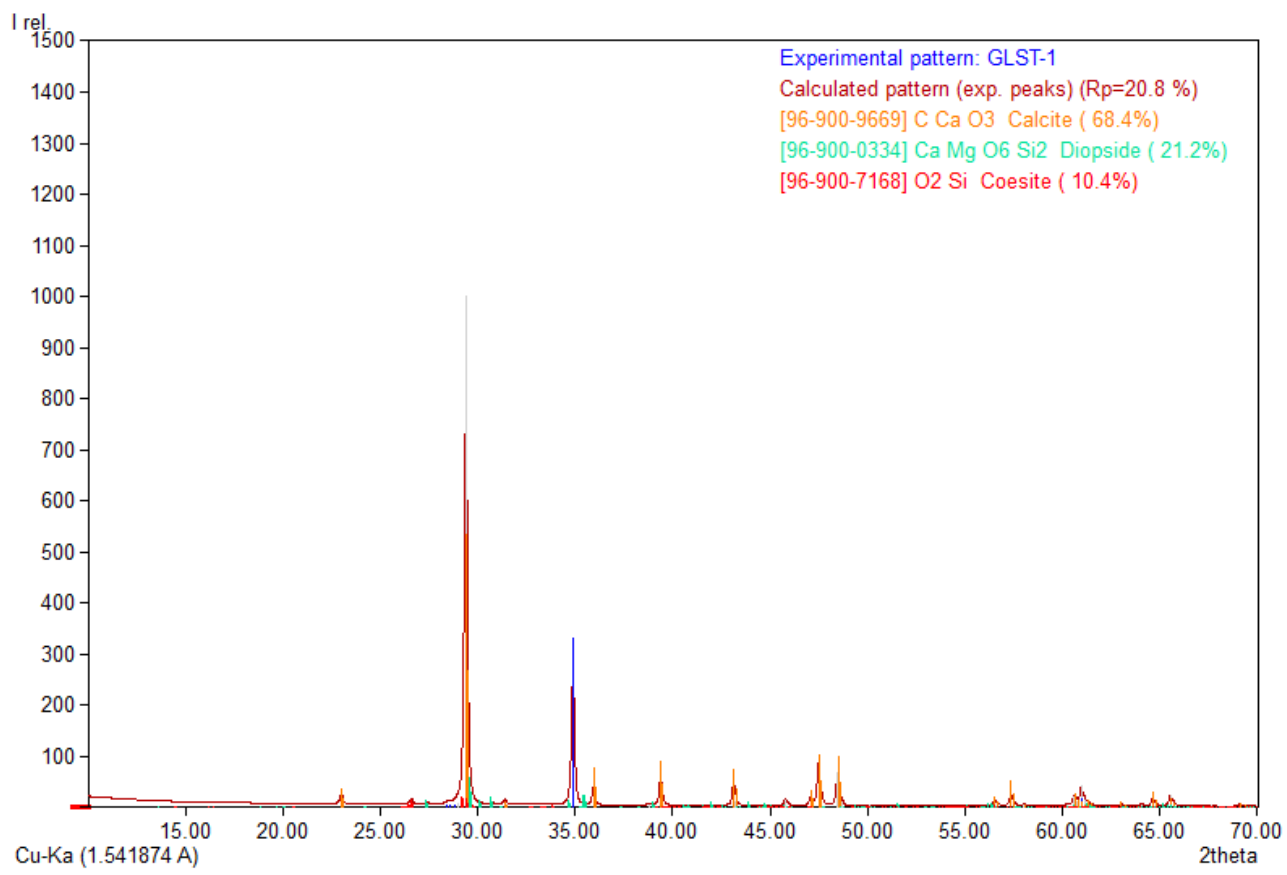

Figure 4: XRD pattern of grayish-white limestone 


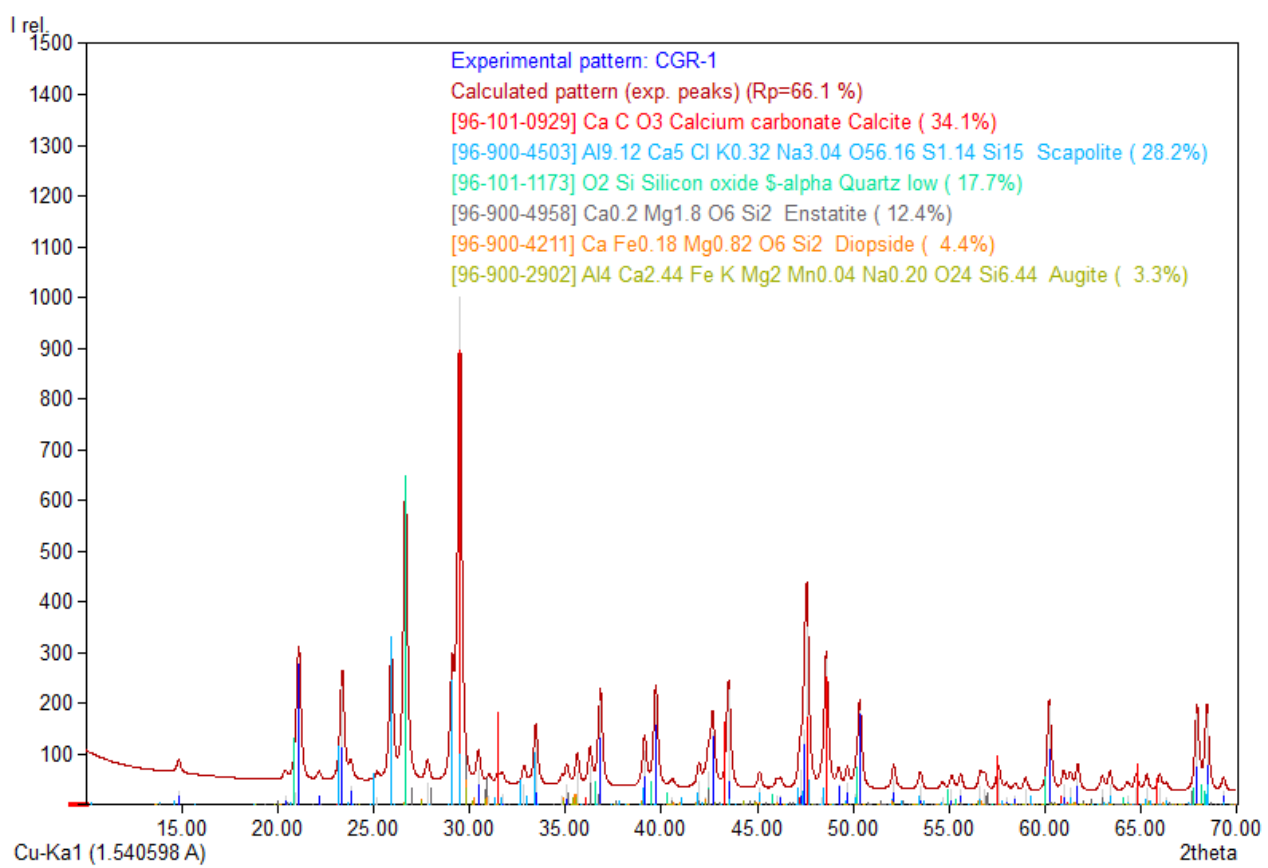

Figure 5: XRD pattern of calc-gneiss

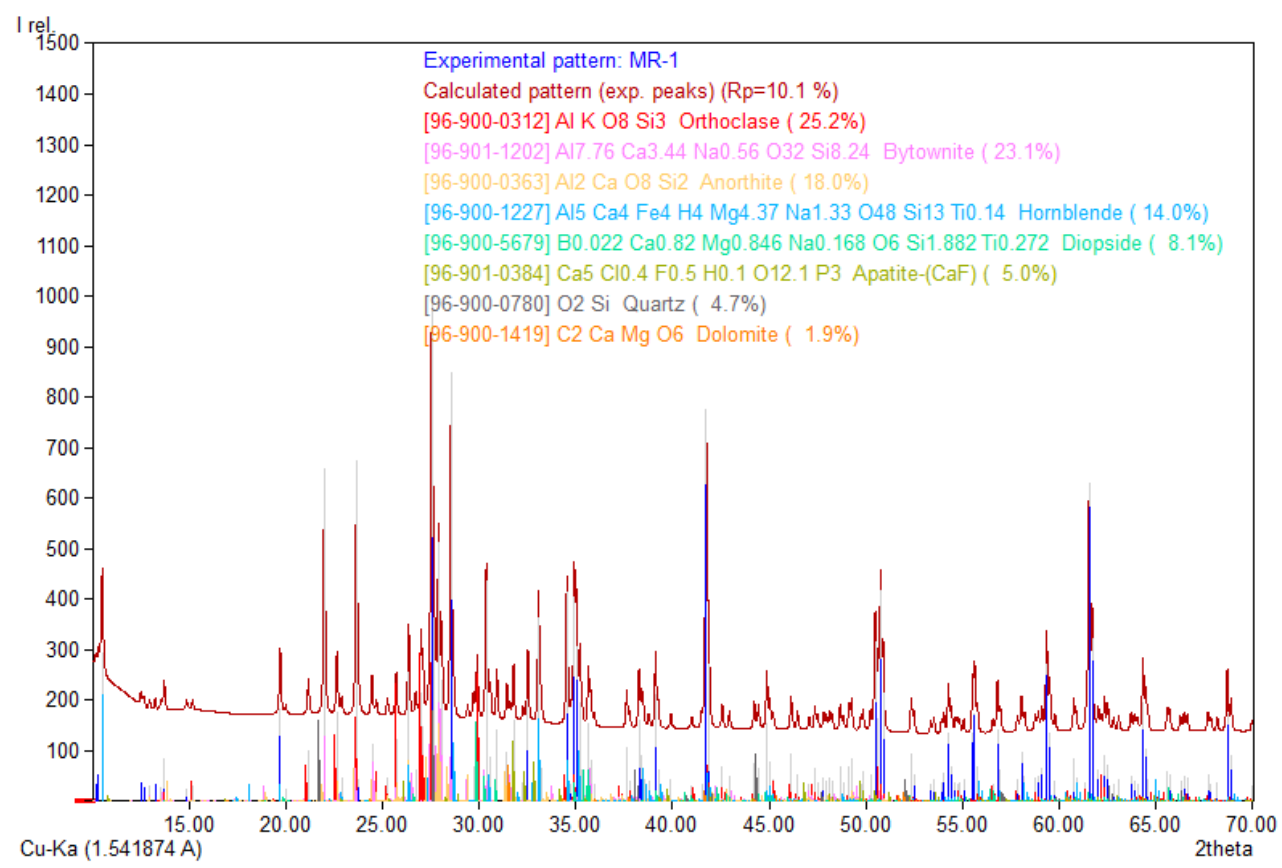

Figure 6: XRD pattern of charnockite 


\section{IV.CONCLUSION}

The XRF and XRD measurements revealed that, the crystalline limestone occurred in the study is a medium grade limestone having an average $\mathrm{CaO}$ of $51.57 \%$. In the limestone band silica is a major concern $\left(\mathrm{SiO}_{2}-9.94 \%\right)$ which seems to be a bit higher and owing to downgrade the limestone quality. The study area crystalline limestone is made up of calcite, quartz and diopside minerals. The pink limestone contains quartz as $\alpha$-quartz (low quartz) and the greyish-white limestone contain quartz as coesite (high quartz).

\section{REFERENCES}

[1]. H.E.Hawkes, “Adaptive Principles of geochemical prospecting.", U.S Geological survey Bulletin 1000-F, pp. 225-355, 1957.

[2]. Indian Bureau of Mines (IBM), "Limestone and other calcareous minerals." Indian Minerals Yearbook, Part III: Mineral Reviews, $52^{\text {nd }}$ ed., January 2015.

[3]. Panda D.K., Sharma N.K. and Gotecha S.K. "Mineral beneficiation potentialities of Archaean limestone for Cement manufacture". Proceedings of the International Seminar on Mineral Processing Technology - 2006, Chennai, India. pp. 297 - 302, 2006.

[4]. Geological Survey of India (GSI), " Geology and mineral resources of Tamil Nadu and Puducherry. ",Miscellaneous Publication, 2014, No.30 Part VI.

[5]. Balachandran, "District Groundwater Brochure, Thoothukudi District, Tamil Nadu", Technical reposrt series, CGWB, March 2009.

[6]. Subburaj A., Dhyanakumar D., Ravichnadran K.," District Groundwater Brochure Thoothukudi District, Tamil Nadu and U.T of Puducherry (2014-2015)", Technical report series, CGWB, Nov. 2015.

[7]. El-Taher, Mohamed Anwar and K. Abdelhalim, "Elemental analysis of limestone by instrumental neutron activation analysis", Journal of Radioanal Nucl Chem (2014) 299:1949-1953.

[8]. Vengadesan R. and Senthil Kumar G.R., "Comparative study on chemical characteristics and minerals in Meretix Casta (Chemistz, 1782) shells of Vellar and Yadayanthittu estuaries, Southeast coast of India.", International journal of advance research I Biology, Engineering, science and technology, vol.2, issue 4, pp.7-15, April, 2016.

[9]. Senthil Kumar G.R. and Vengadesan, R, " Chemical and mineralogical measurements of estuarine clam Meretix Casta shells of Yadayanthittu estiary, Southeast coast of India.", The pharmaceutical and chemical journal, 2016 pp 142-148.

[10]. Gunatilaka H.A and Roger Till, "A precise and accurate method for quantitative determination of carbonate minerals by X-ray diffraction using a spiking technique”, Mineralogical magazine, vol. 38, pp. 481-7, Dec. 1971.

[11]. A.A. Balog, N. Cobirzan, L. Barbu-Tudoran, "Evaluation of limestone with non-invasive analytical methods", Rom. Journ. Phys., Vol. 59, Nos. 5-6, P. 601-607, Bucharest, 2014. 
[12]. Saulius Gražulis, Adriana Das` kevic`, Andrius Merkys, Daniel Chateigner, Luca Lutterotti, Miguel Quiro’, Nadezhda R. Serebryanaya, Peter Moeck, Robert T. Downs and Armel Le Bail. "Crystallography Open Database (COD): an open-access collection of crystal structures and platform for world-wide collaboration", Nucleic Acids Research, 2012, Vol. 40, Database issue, Nov.2011. 